\title{
EFFECTIVE ORGANIZATIONAL CULTURE OF FAMILY FIRMS - THE PERSPECTIVE OF FUTURE SUCCESSORS: A QUALITATIVE STUDY
}

\section{INTRODUCTION}

Family can be described as an institution where one feels secure, respected and needed which is reflected through close relations with relatives based on loyalty, integrity and a sense of belonging. Relations are also the core of business; they decide about its success or failure. The emerging question is what happens when these two areas come into interplay? In fact, since the dawn of time, family has been a working unit where traditions connected with special occupations have been passed on to further generations. Currently, the economic statistics show that over $77 \%$ of companies in Poland comprise family businesses which achieve better ROI (return on investment) results than other entities (GUS, 2015). While family relations may comprise a competitive advantage over other business unit, in Poland, the practice shows that interpersonal conflicts have a detrimental effect on business performance. The common scenario relates to the business and family split, resulting in younger generations migrating to other countries for employment reasons.

Despite the growing interest in family firms as a realm of organizational psychology, there is still a significant lack of theoretical tools, models and empirical research (Carsurd \& Brannback, 2012) which would explain complex functioning of organizations where two systems, family and business, are interrelated. Sirmon, Hitt and Ireland (2007) sustains that the majority of obstacles are based on social

Dr Klaudia MartynowsKa - Department of Psychopedagogy, Institute of Pedagogy, Faculty of Social Sciences, The John Paul II Catholic University of Lublin, correspondence address: Al. Racławickie 14, 20-950 Lublin; e-mail: martynowska.klaudia@gmail.com 
perspective as they pertain to relations which may include competitive advantage of the family businesses over other companies.

The area which has not received significant academic attention is the nature of internal functioning of a company that is organizational culture. Haugh and Mckee (2004) pointed out loyalty, honesty, sense of belonging and trust in the respect to the organizational culture. They stated that attachment to these values varies considerably among employees, depending on employment tenure, subgroups, job position and relation with a supervisor. Wilderom and Van den Berg (2004) introduced organizational culture as shared perceptions of organizational observable practices and procedures. The way organizational culture creates important intangible attributes vary at the organizational and even national level. More importantly, the majority of these attributes are human which leads to the conclusion that they may be defined by assessing human perceptions (DiMaggion, 1997). This sort of research has been mainly conducted in corporations or small businesses, nonetheless family businesses remain an unexplored area in this matter.

The literature review shows that research conducted on family firms has mainly explored issues connected to succession (Morris et al., 1997), ethnicity (Mulholland, 1997), the family home-business interference (Wheelock \& Baines, 2000), management issues in the family such as strategy, recruitment, employment and marketing, mostly in the design of quantitative research. Thus, it is of great importance to gain the kind of in-depth knowledge of successful functioning of family businesses especially from the relational perspective.

The present paper aims at exploring the meaning making of the employees who are future successors with regards to the concepts of successful organizational culture of family firms. The objective is to present and discuss categories, emerged in the qualitative study, which indicate new research areas in family business context.

\section{METHODS}

\section{Research design}

Interpretative Phenomenological Analysis (Smith, 1987) was employed to capture the participant's perception and meaning-making of successful functioning of family business. The focus was placed on content and systematic analysis of a text to identify themes and categories. Face-to-face, semi-structured 
interviews were considered the most suitable primary data collection tool to access this knowledge and to enable flexible, in-depth exploration of the issue.

\section{Research sample}

The sample constituted of 21 participants from different family firms from Poland. 12 males and 9 females, aged 23-43 took part in the study. The sample was purposefully selected as the research explores phenomena within a specific business context. Purposive and theoretical sampling procedures were used to ensure that the sample comprised of one family member from each company who was a potential successor of that company.

\section{Data collection}

The research was conducted in a natural setting for the participants - their company or home, indicated by interviewees prior to previous agreement on taking part in the study. Semi structured interviews were recorded upon participants agreement. The lengths of interviews ranged between 50 and 90 minutes. The aim was to capture the richness and complexity of participants" experience by being an active listener and by allowing the interview to progress down avenues they opened up rather than those dictated by the interview schedule. Some anchor questions used in the interview: "What matters the most when you think about effective interpersonal dynamics of a successful family firm?"; "What would a model relation between the founder and the future successor look like?" "What are the most principal values expressed by all employees of family firms which contribute to the success in a long term perspective?"

\section{Data analysis}

Inductive analysis aimed at exploring the meaning making of followers' functioning in a context of family business. Data driven, open coding analysis allowed identification and categorization of phenomena. The set of categories for a specific topic was obtained, connected with relevant text passages from the material. The scope of analysis is more explorative and there is no pre-formulated set of categories.

\section{Rigour}

Verification in qualitative research implemented into every step of a study constructs a solid product (Creswell \& Plano Clark, 2010) by identification and 
correction of errors prior to including them in a developing model or analysis. Constant and systematic data check, maintaining the focus, establishing the fit of data and the method of analysis, monitoring interpretation makes the qualitative research iterative rather than linear. The verification strategies implemented during the study consist of researcher's responsiveness, methodological coherence, theoretical sampling and sampling adequacy, an active analytical stance.

\section{Ethics}

The research was conducted in accordance with Polish Psychological Society guidelines. The aim and educational purpose of the research were presented to the participants in a clear and comprehensive way. The participants agreed upon recording and transcription of their accounts by singing the consent forms. The names have been changed and any other identifying information amended in order to preserve confidentiality and anonymity. Participants were informed about their right to withdraw themselves or their data at any time during the research.

\section{RESEARCH FINDINGS}

The results of interpretive phenomenological analysis involve inductive categories which reflect participants' understanding of organizational culture characteristics, mainly pertaining to effective relations within family firms. The categories emerged on the basis of meaningful extracts of the participants' accounts.

Category 1: Sense of "we"

Many participants underlined that working in a family business and its success it tightly connected to the fact that family performs business activity as a team which jointly makes effort to gain profits. 'We have this rule that it's not like everyone works for themselves but we all work together for the whole family and then we share profits equally [Participant 10].' Job satisfaction is tightly linked with personal satisfaction when actions are being taken jointly towards common goals. 'This job gives me a lot of satisfaction when I look at machines, at everything we achieved together with my family - my team. That we did it ourselves and it makes me happy' [Participant 19]. Although family is the prime source of a sense of belonging - family business does not seem to be so obvious in this matter. Participants stressed factors which makes them feel that family firm is the place they should work in. 'It makes me feel that that this is my place, my home' [Participant 2]. 
Despite being a part of the family, the majority of participants expressed a deep need to experience a sense of collective identity in business context which is reflected in commonly used expressions such as "we," "together," "jointly."

Category 2: Entrepreneurial upbringing

This category is linked to developing proactivity in children by parents who run family businesses which includes arranging part time jobs during school breaks, providing an opportunity to earn money to cover some of the living expenses and engaging a child to help parents in a business from early adulthood. 'Parents would make me realise that if I want to achieve something I have to work my way up' [Participant 8]. It seems that at first children did not come to terms with that fact but eventually the attitude of their parents turned out to be crucial in developing entrepreneurial mindset of their children. 'I was mad at parents that I had to earn my own money for a course and test and my friends got money from their parents. But, joining a company for real and taking on more duties was not a problem for me' [Participant 2]. 'I had to pay for my studies myself [...]. Their attitude taught me accountability and I'm very thankful for that' [Participant 7]. It suggests that parents who implemented entrepreneurial practices in upbringing of their child contributed to their successful functioning within their family firm.

\section{Category 3: Trust}

Naming this category was straightforward as most participants refereed to this notion directly: 'My father trusts me more than my sisters' [Participant 2]. Trust was associated with the role of the founder (in all cases it was father) who entrusted future successors - and this fact influenced their self-belief. 'My father leaves a lot of freedom to me; I mean in the health center [...] he puts a lot of trust in me' [Participant 2]. Future successors repeatedly mentioned how trust from the father (founder) enhances their motivation and engagement to perform even better: 'I just feel that he trusts me and I don't want to let him down [...] I want to prove myself to him' [Participant 7].

Category 4: Immediacy in communication

This category alludes to openness and freedom in expressing one's thoughts and opinions. Case studies presented in the current research shows that this category lays on the spectrum with restricted immediacy on one end and complete freedom on the other end.

'We can be honest with each other [...] we can speak freely of doubts' [Participant 4]. 'I guess it's the best thing that I can tell my boss who is my father 
nearly everything' [Participant 17]. On the other hand, a lack of immediacy was mentioned as the biggest obstacle in communication: 'It was difficult for us to talk openly about big things. We had brief conversations about daily stuff but some things remained untouched and it was a big problem for us' [Participant 3].

\section{DISCUSSION}

The research findings expand the understanding of family business organizational culture by exploring the perspective of future successors. In the light of previous research, honesty, loyalty, trust and respect between organizational members are embodied in the term of "family culture." Haugh and McKee (2004) shows that even within the family firm, attachment to these values differed between individuals in terms of their membership of different subgroups, position in the organization, length of employment, and their relational ties to the ownermanager of family. The present study showed that trust, sense of "we," entrepreneurial upbringing, and immediacy in communication may comprise a model explicating the complex organizational culture of family businesses.

Trust has been widely researched and proved to be fundamental aspect of relationships between parents and children - parents shared more information with their children and engaged in family activities more frequently when they trusted their children (Kerr, Stattin \& Trost, 1999). It is associated with greater closeness, higher relationship quality, and more positive communication between the people who trust-trusters and the people who are trusted-trustees. Previous research demonstrates that trust varies considerably across family members and across family relationships (Buist et al., 2004). Thus, it would be interesting to investigate factors affecting trust within family who also conduct a business activity together.

Lack of immediacy in communication restrains a follower from expressing his or her expectations which in turn inhibits a sense of belonging. Information and transparency empower people; vagueness keeps them off-balance and anxious. Most participants in the present study mentioned that they encountered a large amount of vague situations resulting from the fact that other family members struggled with setting expectations and being candid about it in a business context. There is a missing conceptualization of the notion of immediacy in communication, thus there is a need to settle theoretical framework and conduct research on that. 
Sense of "we" may be associated with the sense of belonging, as McClure and Brown (2008) found that the strongest sense of belonging that emerged was the discovery of self within a job. It is vital for employees to find their place in a company, which was repeatedly noted by interviewees in the current research, despite the feeling of belonging to the family unit. Yet, sense of "we" as the separate concept has not been widely researched yet.

The notion of entrepreneurial upbringing has not been explicitly introduced in the literature. It may be linked to developing proactivity in children by parents who run family businesses. Proactivity, according to Parker et. al., (2006) plays role in the extent of inclination or ability to reshape the job to suit personal needs. The climate of psychological safety is associated with higher levels of proactive learning and voice behaviors (Edmondson, 1999). This psychological safety can be provided by parents before and during their child operate in their family business. Kirkwood (2007) elaborated whether entrepreneurial spirit may be ignited by parents, yet the analysis has not fully explored how parents may bring up a child to become an entrepreneur. As some may argue that entrepreneurship is a matter of predispositions (usually inherited via specific personality traits), there may occur some contextual factors in upbringing which facilitate or inhibit developing entrepreneurial behavior of a child.

\section{LIMITATIONS AND FUTURE RESEARCH DIRECTIONS}

This is relatively small, qualitative study that is limited to a specific cultural group - Polish future successors of family firms. The particular social and cultural forces have not been explored in this study. Further qualitative studies may address the research question focused on how organizational culture of a family firm is extended across multiple generations. Future research may employ quantitative design to conceptualize the notion of organizational culture of family firms and create its model. A correlational study could explore interrelations within trust, sense of "we," entrepreneurial upbringing, and immediacy in communication. Psychometric tools may be designed to measure trust, its levels and causes of changes among family members. 


\section{REFERENCES}

Buist, K.L., Deković, M., Meeus, W. \& van Aken, M.A. (2004). The reciprocal relationship between early adolescent attachment and internalizing and externalizing problem behaviour. Journal of adolescence, 27(3), 251-266.

CARsurd, A.L. And BrannBaCk, M. (2012). Understanding Family Business. New York: Springer.

DiMaggio, P. (1997). Culture and cognition. Annual review of sociology, 23, $263-287$.

Edmondson, A. (1999). Psychological Safety and Learning Behavior in Work Teams. Administrative Science Quarterly, 44(2), 350-383.

GUS (2015). Mate $i$ średnie przedsiębiorstwa niefinansowe $w$ Polsce $w$ latach 2009-2013. Warszawa: Zakład Wydawnictw Statystycznych.

Haugh, H. \& McKeE, L. (2004). The cultural paradigm of the smaller firm. Journal of Small Business Management, 42(4), 377-394.

HitT, M.A., Sirmon, D.G., IRELAnd R.D. (2007). Managing firm resources in dynamic environments to create value: looking inside the black box. Academy of Management Review, 32(1), 273-292.

Kerr, M., Stattin, H. \& Trost, K. (1999). To know you is to trust you: Parents' trust is rooted in child disclosure of information. Journal of adolescence, 22(6), 737-752.

KIRKWOOD, J. (2007). Igniting the entrepreneurial spirit: is the role parents play gendered? International Journal of Entrepreneurial Behavior \& Research, 13(1), 39-59.

McClure, J.P. \& Brown, J.M. (2008). Belonging at work. Human Resource Development International, 11(1), 3-17

Morris, M.H., Williams, R.O., Allen, J.A. \& Avila, R.A. (1997). Correlates of success in family business transitions. Journal of business venturing, 12(5), 385-401.

Mulholland, K. (1997). The Family Enterprise and Business Strategies. Work Employment \& Society, 11(4), 685-711.

PARKer, S.K., Williams, H.M. \& TuRner, N. (2006). Modeling the antecedents of proactive behavior at work. Journal of applied psychology, 91(3), 636-652.

WHEELOCK, J. \& BAINES, S. (2004). Balancing work and family life in disadvantaged small business households. In: J. TARGALSKI (eds.), Entrepreneurship, Employment and Beyond (pp. 157-12). Krakow: University of Economics Publishers.

Wilderom, C.P.M., Van den Berg, P.T., Glunk, U. \& Maslowski, R. (2001). Beyond the handbook: organizational culture. In $61^{\text {st }}$ Academy of Management Annual Meeting 2001: How Governments Matter. Washington, United States.

\section{EFEKTYWNA KULTURA ORGANIZACYJNA FIRM RODZINNYCH Z PERSPEKTYWY PRZYSZŁYCH SUKCESORÓW. BADANIE JAKOŚCIOWE}

\section{Streszczenie}

Rodzina jest źródłem zaufania, lojalności i poczucia przynależności w oparciu o relacje, które są również podstawą biznesu. $Z$ tego względu, wspólne prowadzenie firmy przez rodzinę wydaje się logiczne. Niemniej jednak, podwójna rola odgrywana przez członków rodziny może utrudniać funkcjonowanie firmy. Niniejszy artykuł ma na celu interpretację rozumienia zjawiska efektywnej kultury organizacyjnej firm rodzinnych przez przyszłych sukcesorów. W badaniu wzięło udział 32 sukcesorów. Interpretacyjnej analizie fenomenologicznej (IPA) poddano częściowo ustrukturowane wywiady pogłębione. Wyniki przedstawiają następujące kategorie: zaufanie, poczucie „my”, przed- 
siębiorcze wychowanie oraz bezpośredniość w komunikacji, składające się na autorski model objaśniający złożoną kulturę organizacyjną firm rodzinnych. Przedstawiono kierunki przyszłych badań ilościowych oraz wartość aplikacyjną w obszarze przedsiębiorstw rodzinnych.

Słowa kluczowe: firma rodzinna; relacje rodzinne; kultura organizacyjna; sukcesorzy; badanie jakościowe.

\title{
EFFECTIVE ORGANIZATIONAL CULTURE \\ OF FAMILY FIRMS - THE PERSPECTIVE OF FUTURE SUCCESSORS: \\ A QUALITATIVE STUDY
}

\begin{abstract}
Summary
Family is the source of trust, loyalty and sense of belonging based on relations which are also the core of business. While running a business by family seems a logical thing to do, a double role played by family members may impede company's functioning. The present paper aims at exploring the meaning making of the employees who are future successors with regards to organizational culture characteristics associated with effective business performance of family firms. 32 future successors took part in the study. Semi-structured interviews were analyzed through Interpretative Phenomenological Analysis. The findings comprised following categories: trust, sense of "we," entrepreneurial upbringing, and immediacy in communication which may comprise a model explicating complex organizational culture of family businesses. The results provided extensive future research directions into the field of family business.
\end{abstract}

Key words: family firm; family relations; organizational culture; future successors; qualitative study. 